\title{
Borax as a Non-Food Grade Addivite in the Perspective of Foof Safety and Human Resources Formation: A Literature Review
}

\author{
Yunita Satya Pratiwi ${ }^{1}$, Dina Mustika Rini ${ }^{1}$, Hadi Munarko ${ }^{1}$, Hadi Prayitno 2 , Ristya Widi Endah \\ Yani ${ }^{3}$, Nadia Shoukat ${ }^{4}$, Kaleem Ahmad 5 \\ ${ }^{1}$ Department of Food Technology, Faculty of Engineering, Universitas Pembangunan Nasional "Veteran" \\ Surabaya, East Java, Indonesia \\ ${ }^{2}$ Master Program of Health Science, University of Jember, Jember, Indonesia \\ ${ }^{3}$ Faculty of Dentistry, University of Jember, Jember, Indonesia \\ ${ }^{4}$ Department of Zoology, Faculty of Science and Technology, Government College University Faisalabad, \\ Punjab, Pakistan \\ ${ }^{5}$ Faculty of Rehabilitation and Allied Health Science University of Riphan International, Islamabad, Paki- \\ stan
}

${ }^{*}$ Corresponding author:

E-mail:

yunitasatyapratiwi@gmail.com

\begin{abstract}
Many foodborne disease cases are still existing in Indonesia and worldwide. Chemicals that act as non-food grade additives is one of the cause. Borax is a chemical which still widely used for food in the community. The purpose of writing this scientific article is to analyze the impact of using borax as a nonfood grade additive from the perspective of food safety and human resource formation. This article was based on scientific phenomena that occurred in studies conducted by the author in private, which was then analyzed more deeply based on a study of theories. As mentioned in government law, the use of borax for food additives is prohibited. However, borax is still widely used as food additives in the communities. This phenomenon is a threat to the assurance of food security for individuals and society, which in turn will have an impact on the output quality of human resources needed as the subject of future development. Several studies, investigated the negative effects of borax on the biological function of living things, showed that the use of borax significantly affects food safety in terms of human resources formation. Therefore, it needs both a preventive and curative solution for individuals, groups, and the government in an integrated manner. The use of borax in food is a threat to the assurance of food safety for individuals and society, which in turn will affect the quality of human resources so that a preventive and curative solution is needed.
\end{abstract}

Keywords: Borax, a non-food grade addtivite, food safety, human resources formation

\section{Introduction}

Well, access to healthy, nutritious, safe, and healthy food is one of all human beings' rights. In fact, for many people in Indonesia and even in the whole world, especially for those living in lowincome communities, healthy food is simply out of reach. Foodborne disease, an illness caused by food contamination by either microorganism or dangerous chemical substances, is the impact of that phenomenon (Nadiya \& Asharina, 2016).

WHO (World Health Organization) estimate that unhealthy food is responsible for 600 million foodborne disease cases, 420.000 deaths every year in the whole world, and even 33 million disability-adjusted life year (DALYs). Moreover, $40 \%$ of a toddler suffers from a foodborne disease with $29 \%$ deaths every year (World Health Organization, 2020).

\section{How to cite:}

Pratiwi, T. S. et al. (2020). Borax as a non-food grade additivr in the perspective of foof safety and human resources formation: A literature review. ${ }^{\text {st }}$ International Conference Eco. Innovation in Science, Engineering, and Technology. NST Proceedings. pages 119-126. doi: 10.11594/ nstp.2020.0518 
The prevalence of the foodborne disease in Indonesia getting an increase. In 2014, the Individual Food Consumption Survey (SKMI) found around 200 reports of food poisoning extraordinary events (KLB) occurring in Indonesia per year. In 2010, there were 429 reported cases of foodborne disease and it is believed that the real number is much higher than that since only around $63 \%$ of provinces report the case.

The highest food poisoning KLB was reported in West Java with 163 incidents, 10926 total cases, 13 deaths $(0.1 \%$ case fatality rate), and in Central Java with 163 incidents, 8428 cases, and 22 deaths $(0.3 \%$ case fatality rate). Province of NTT has the highest number of deaths number with 38 incidents, 6449 cases, and 40 deaths ( $0.6 \%$ case fatality rate). While in North Kalimantan, North Maluku, and West Papua have not reported the incident (Arisanti, Indriani, \& Wilopo, 2018).

In 2011, BPOM data showed 128 food poisoning KLB in Indonesia. Around 29.69\% (38 KLB) was caused by microbial contamination, while $14.84 \%$ (19 KLB) was caused by chemical contamination (Fajri, 2013). Chemical hazards can be caused by banned additives or non-food grade additives such as borax, formaldehyde, rhodamine $\mathrm{B}$, and methanal yellow.

Borax and formaldehyde have been prohibited as food additives following the Regulation of the Minister of Health of the Republic of Indonesia Number 033/2012 about Food Additives (Kementerian Kesehatan RI, 2013). In facts, there are still 50\% of street food seller use borax and formaldehyde to preserve their food in Jakarta (Dinas UMKM DKI Jakarta, 2015). Meanwhile, a previous study found that 33 wet noodles sold in the traditional markets of Bengkulu, $66.66 \%$ of it containing borax (Widelia, Farazald, \& Narti, 2017).

Based on the Food Safety Survey on 1,504 Food Household Industries (IRTP) in 18 provinces by BPOM RI in 2009, there is a misuse of hazardous materials such as formalin (4.89\%), borax (8.80\%) and rhodamine B and methanyl yellow (4.89\%) on IRTP products (BPOM RI, 2013). These survey showed that the use of borax tends to be relatively high compared to formaldehyde and non-food grade additive.

The negative effect of borax on our health is associated with the residue which can cause a systemic effect in the body. Borax can further damage the liver, stomach, small intestine, large intestine, testicular organ infertility, and ovaries, and stimulate the growth of cancer cells. Moreover, it also can attack cells, especially in the mitochondria, and accumulate in the cytoplasm which can interfere with metabolism. At high doses in the body, borax can cause symptoms of headache, vomiting, diarrhea, stomach cramps, low blood pressure, anemia, fever, and other internal organ damage, including the brain, and even death (Dourson et al., 2003; Lewis, 2002).

In summary, based on the negative effects of borax as a non-food grade additive in food and ready-to-consume food, it is certainly undeniable that this chemical will have a negative impact even in the short, medium, or long term use. It can become a threat to food security in general and further influence the input, process, output, and outcome of the physical and mentally growth of healthy humans.

In this study, we will explain how borax as non-food grade additives from the perspective of food safety and human resources formation in detail. Hopefully, this study can give a better understanding of the importance of safe food to consume to generate high quality and healthy human resources. Finally, human resources with good quality are expected to be the subject of reliable development both in Indonesia and in the world. This study aimed to analyze the impact of using borax as a non-food grade additive from the perspective of food safety and human resource formation.

\section{Research Method}

The method of the writing of this article was based on scientific phenomena that occurred in studies conducted by the author in private from September to July 2015 (Pratiwi, 2018), which was then analyzed more deeply based on a study of theories about borax, food safety, formation 
human resources and their relationship each other was taken from various research journals and textbooks.

There were no statistical tests used in this article. An explanation of the use of borax in the community as a non-food grade additive in the perspective of food safety and human resource formation was based on the author's research phenomenon, then along with the interactions between all the variables above that will occur in-depth based on a literature review.

\section{Results and Discussion Borax}

Sodium tetraborate decahydrate or commonly known as borax is a chemical compound that has a low toxicity mineral content. The chemical formula embedded in borax is $\mathrm{Na}_{2} \mathrm{~B}_{4} \mathrm{O}_{7} \cdot 10 \mathrm{H}_{2} \mathrm{O}$.In the general market, borax has a powder or fine form that contains boric oxide (B203), sodium oxide, and water. Besides, borax is a chemical compound that has alkaline properties and easily dissolves in water. As a chemical compound, Borax is partly stored in fat tissue and mostly stored in bone tissue when consumed by organisms. Borax, boric acid compound (boric acid), is a chemical which used as a raw material in wood preservatives, detergents, and ant-killing agent's manufactures. Also, it is used as an additive in ceramics, glass, skin ointments, and sprue drugs (borax glycerin) manufacturers (Pongsavee, 2009; EFSA, 2013). Borax, the main ingredient in wood preservative, is often misused by the community. Indonesian people often use borax as an additive in some food such as meatballs, empek-empek, tofu, and crackers. Borax can give a chewy and savory flavor to meatballs (BPOM, 2014). However, the use of borax as an additive in food is prohibited. Based on Article 3 letter (b) of the Joint Regulation of the Minister of Home Affairs of the Republic of Indonesia and the head of the Food and Drug Administration of the Republic of Indonesia Number 43 of 2013 and Number 2 of 2013 concerning Control of Hazardous Materials Misused in Food, it states that borax is one of the hazardous ingredients in food. Also, in the Regulation of the Minister of Health of the Republic of Indonesia Number 033 of 2012 concerning Food Additives, part of Appendix II states that Borax / Boric acids are compounds and chemicals that are prohibited from being used as food additives.

Borax is a hazardous additive in food, the use of borax endangers human health. Borax consumption does not directly affect the health but it will slowly give a side effect due to the gradually cumulative accumulation of borax in the body (Subiyakto, 1991). According to Nevrianto (1991) consuming foods containing borax will interfere with the nervous system, kidneys, and liver. Suadayana, Arania, \& Alfarisi (2014) explained that borax consumption hurts the kidney with the expansion of blood vessels, destruction of proximal tubular epithelial cells, and interstitial lymphocyte inflammatory cell infiltration.

Meanwhile, Suadayana, Arania, \& Alfarisi (2014) also explained that the higher borax administration in Wistar rats, the more severe kidney damage. Also, consuming foods containing borax can disturb the liver system. Regular consumption of borax will damage cell membranes and hepatic parenchyma cells. Hepatic parenchyma cell damage is caused by the active group in borax, namely $\mathrm{B}-\mathrm{O}-\mathrm{B}(\mathrm{B}=0)$, which binds to proteins and lipids, which results in the occurrence of lipid peroxides. Lipid peroxides cause the cell membrane to be rich in lipids which results in cell permeability damage. Cell permeability damage has an impact on disrupting the flow of all substances in and out of cells (Adinugroho, 2013).

A high number of lipid peroxidase will increase the free radicals of ROS (Reactive Oxygen Species) and RNS (Reactive Nitrogen Species) which then damage the integrity of the hepatic cell (Yusuf \& Nisa, 2015).

\section{Food safety}

Food safety is a basic human need that guarantees the fulfillment of every citizen's rights. Therefore, food must be sufficient in quantity, quality, safe, nutritious, varied at prices, and affordable. Based on Government Regulation no. 86 of 2019 concerning Food Safety states that: food is 
everything that comes from biological sources of the agricultural, plantation, forestry, fishery, livestock, water, and water products, both processed and unprocessed which are designated as food or drink for human consumption, including food additives, food raw materials and other materials used in the process of preparing, processing or making food or beverages.

Law of the Republic of Indonesia No. 18 of 2012 concerning Food and Government Regulation No. 86 of 2019 concerning Food Security regulates food safety in Indonesia. Food safety also consists of food sanitation, regulating food additives, regulating genetically engineered food products, regulating food irradiation, establishing food packaging standards, providing food safety and quality assurance, guaranteeing halal products for those who are required.

Food safety, both in the world and in Indonesia, is the main aspect of quality and safe food products. Certainly, food safety is a major aspect of improving good human resources. Food safety ensures the food products are free from chemical and biological contamination, also other substances that can interfere with the health and lead to diseases.

Food safety condition in Indonesia still needs a lot of concern due to the lack of attention from the government, society (consumers), and even the food industry. Based on BPOM data, food poisoning in Indonesia is mostly caused by home industries (39\%), followed by the foodservice industry (20\%), the snack industry (21\%), and the processed food industry (13\%).

Based on Article 3 letter (b) of the Joint Regulation of the Minister of Home Affairs of the Republic of Indonesia and the head of the Food and Drug Administration of the Republic of Indonesia Number 43 of 2013 and Number 2 of 2013 concerning Control of Hazardous Materials Misused in Food, it states that borax is one of the hazardous ingredients in food. Also, in the Regulation of the Minister of Health of the Republic of Indonesia Number 033 of 2012 concerning Food Additives, part of Appendix II states that Borax / Boric acids are compounds and chemicals that are prohibited from being used as food additives.

The use of borax as a food additive can threaten food security, especially for the Indonesian people. Borax can cause chemical contamination in the food. Chemical contamination can be disturbing, harmful, and dangerous. The chemical contamination in food consumed by living things will present its danger and have an impact on public health. A large amount of borax enter into the body can lead to serious health problems, such as intestinal disorders, stomach disorders, liver, and even acute kidney failure which can cause death. According to Nevrianto (1991) consuming foods containing borax will interfere with the nervous system, kidneys, and liver. Therefore, full consideration is needed in choosing food to avoid food with borax supplementation. Also, people can use ingredients which natural and safer for health, such as carrageenan.

\section{Human resources formation}

The quality of human resources (HR) is the main factor needed in implementing national development. Food and nutrition factors play an important role in achieving good quality human resources (Depkes RI, 2005). Good nutrition will generate high-quality human resources which healthy, smart, physically strong, and productive. It is necessary to improve nutrition in the entire life cycle, starting from pregnancy, infants and toddlers, pre-school, elementary school, and MI children, adolescents, and adults to the elderly (Heath, Deanne, \& Panaretto, 2005).

Food is a basic human need and right, therefore the fulfillment of food is the right of every individual. Fulfillment of nutritious, safe, and healthy food is crucial to get good human resources quality. Therefore, every individual must selectively choose their foods. The government, as the executor of policy, must support food safety by providing a well-managed food and nutrition system in their country.

To control food products contaminated with chemical additives, the government needs to take several steps as follow: 1 ) issuing a policy prohibiting the use of chemical food additives that are harmful to health; 2) supervision of food products in circulation; 3) law enforcement against business actors who violate the prohibition of using food additives; 4) disseminating information to the community (Zazili, 2016). 
Food safety assurance for every citizen only can be achieved if the government enforces the law of prohibiting food additives (non-food grade additives) and regulate the violations law. Hopefully, the formation of high-quality human resources can be achieved as national development expected.

\section{Relationship of food safety and human resources establishment}

Food safety within the scope of the use of non-food grade additives such as borax, of course, will affect the input, process, output, and outcome of human resources that will be produced later. The relationship between two variables which being connected can be explained by empirical facts based on the previous study. Several studies that show the negative effect of the use of borax in food on the biological functions of living things, including research conducted, will be explained below:

\section{Suadayana, Arania, \& Alfarisi (2014)}

Research title: The difference in the effect of borax administration on the kidney organ histopathology of the Wistar line rats (Rattus norvegicus). In this study, it showed that giving borax to the body hurts the kidneys, widening of blood vessels, destruction of proximal tubular epithelial cells, and infiltration of interstitial lymphocyte inflammatory cells. The higher the dose of borax, the higher the damage on the kidney.

\section{Adinugroho (2013)}

Research title: The effect of gradual doses of borax on the macroscopic and microscopic images of the liver for 28 days (Study on Wistar rats). This study shows that consuming borax regularly will damage the hepatic cell membrane and damage the hepatic parenchymal cell. Hepatic parenchyma cell disruption was caused by the active group in borax, $\mathrm{B}-\mathrm{O}-\mathrm{B}(\mathrm{B}=\mathrm{0})$, which binds to proteins and lipids which lead to the occurrence of lipid peroxides. The occurrence of lipid peroxide causes cell membranes rich in lipids which lead to cell permeability disruption. The cell permeability disruption affects the selectivity of substances to enter into the cell.

\section{Tatukude, Loho, \& Lintong (2014)}

Research title: Histopathological overview of Wistar rat liver fed borax. This study showed that the rat fed by borax has liver cell enlargement and has a blackish-brown color. $20 \mathrm{mg}, 30 \mathrm{mg}$, and $40 \mathrm{mg}$ of borax can cause liver damage. Also, animal liver cells also undergo hydroponic degeneration and fibrolase proliferation.

\section{Mayasari \& Mardiroharjo (2012)}

Research title: The effect of sub-acute oral borax on the occurrence of testicular atrophy of male white rats (Rattus Novergius, strain Wistari). This study showed that oral administration of borax decreased the size or diameter of male white rat's testes. However, oral administration of borax did not cause a decrease in testicular weight in male white rats.

\section{Puspadewi (2012)}

Oral alpha-lipoic acid (ALA) can reduce malondialdehyde (MDA) levels in the blood of boraxinduced in Wistar rat (Rattus norvegicus). The results showed that borax was a source of free radicals for rats. The levels of free radicals in mice caused by borax can be suppressed by using Alpha Lipoic Acid (ALA).

Based on these studies, it can be seen that the use of borax as a non-food grade additive in food hurts the biological functions of the living body. The use and consumption of borax both in the long and short term will hurt the health status of living things, especially humans. Therefore, good food quality, especially food safety, greatly determines the quality of human resources in the 
short and long term in terms of health, as well as guarantees the quality of human resources in the future.

\section{Solution}

Preventive

The preventive method, an effort to prevent the borax and other toxic chemicals use to minimize the negative impacts of borax existence, are as follows:

a. The government, as a policymaker, must make strict and controlled regulations for the distribution of borax sales in the community

b. The government must make strict regulations for any violation of the misuse of the use of borax for food.

c. Borax sellers must have official permission from the government.

d. The buyer must also have an official document and be responsible for the intended use of the borax purchased.

e. Systematic and continuous guidance on prohibited food grade and non-food grade additives, for food producers ranging from street vendors (street vendors) to industrial levels

f. Systematic and continuous guidance from the community level to the individual level as consumers regarding prohibited food grade and non-food grade additives

g. Socialization by the government, non-governmental organizations, and academics on how to easily and practically know the presence of borax or other non-food grade additives in food

h. Efforts to find a substitute for borax as a food preservative and thickener with natural ingredients that are safe through research.

i. Efforts to replace borax as a food preservative and thickener with natural ingredients or other chemicals that are not prohibited.

j. Cook your food to be consumed by collecting lots of good recipes and setting aside special time for cooking.

k. Choose a food manufacturer that is certified or of good quality and trusted.

l. Choose good quality foods (physical and chemical), especially those that are low in saturated fat, and pay attention to hygienic requirements. Even though borax is only found in small amounts in fatty tissue, reduce the intake of saturated fats such as meat or fried foods.

$\mathrm{m}$. Increase insight and knowledge about the physical characteristics of foods containing borax or other non-food grade additives

\section{Curative}

The curative method, efforts to treat the human when borax or other toxic chemicals have entered into the body, are as follows:

a. Drink enough water every day, at least 2 liters per day. Water is the most effective natural ingredient for getting rid of toxic chemicals in the body. Especially water-soluble toxic chemicals such as borax.

b. Regularly consuming natural ingredients (fruits and vegetables) which are rich in antioxidants and fiber to reduce the bad effects of consuming foods containing borax or other non-food grade additives (which are sources of free radicals) which accidentally enter our body, for example, mangosteen peel extract (Pratiwi, 2018; Puspadewi, 2012).

c. Do regular exercise to break down fat into energy naturally, because chemical toxins (fatsoluble) that enter the body are stored in the body, especially in body fat (which contains saturated fatty acids). Apart from regular exercise and sweating it will be effective in removing toxic chemical toxins from the body. 
d. For religious believers who believe and can practice it, fasting regularly is an effective way to detoxify toxic chemicals cheaply and effectively. Because it provides an opportunity for the internal organs of the body (stomach, intestines, liver, kidney, pancreas, and heart) to detoxify toxic chemicals and rejuvenate the skin (Hardinsyah, 2011)

\section{Conclusion}

Borax is a chemical which widely used as a non-food grade additive, although its use has been prohibited by the government. Food security is a basic human need and right of every citizen. The presence of borax in food as a non-food grade additive is an act of violation of the law that threatens the assurance of food security for the community, which in turn will hurt the health of individuals and society, and can even lead to death. Food and nutrition factors play an important role in forming quality human resources. One of the most important areas is food safety which is guaranteed and is also supported by strict regulation and law enforcement by the government. There is a significant effect of food safety on human resource formation. This is proven by the results of scientific research on borax and its effect on the biological functions of living things. This problem can be solved by preventive and curative efforts, which consist of the solution for individuals, groups, and the government.

\section{Acknowledgment}

I would like to express my very great appreciation to Dina Mustika Rini, Hadi Munarko, Anggun Pratiwi, Rizqi Muzayyanah, Hadi Prayitno, Ristya Widi Endah Yani, Nadia Shoukat, and Kaleem Ahmad for their valuable and constructive suggestions during the planning and development of this scientific article. Their willingness to give their time so generously has been very much appreciated.

\section{References}

Adinugroho, N. (2013). Pengaruh pemberian boraks dosis bertingkat terhadap perubahan gambaran makroskopis dan mikroskopis hepar selama 28 hari (studi pada tikus wistar). Fakultas Kedokteran, Universitas Diponegoro.

Arisanti, R. R., Indriani, C., \& Wilopo, S. A. (2018). Kontribusi agen dan faktor penyebab kejadian luar biasa keracunan pangan di Indonesia: kajian sistematis. Berita Kedokteran Masyarakat (BKM Journal of Community Medicine and Public Health), 34(3), 99106.

BPOM. (2014). Bahaya boraks dan formalin (brosur online). http://sib3pop.menlhk. go.id/ uploads/Brosur/Brosur-Boraks.pdf. Depkes RI. (2005). Pedoman perbaikan gizi anak sekolah dasar, dan Madrasah Ibtidaiyah. Jakarta: Direktorat Gizi Masyarakat Dinas UMKM DKI Jakarta. (2015). Dinas UMKM DKI: 50 persen PKL Makanan di Jakarta Pakai Boraks. Retrieved from JPNN.com: https://www.jpnn.com/news/dinas-umkm-dki-50-persen-pkl-makanan-di-jakarta-pakai-boraks

Dourson, M., Maier, B., Meek, F., Bareille, R., \& Baquey. (2003). Boron tolerable intake re-evaluation of toxocokineticsfor data derived uncertainty factors. Biol. Trace Elem.Res, 66(1-3):453-463.

European Food Safety Authority (EFSA). (2013). Scientific opinion on the reevaluation of boric acid (E 284) and sodium tetraborate (Borax) (E 285) as food additives and nutrient sources added to food (ANS). EFSA Journal, 11(10), 3407, 1-53.

Fajri, W. (2013). Sebab dan cara cegah kontaminasi makanan. Retrieved from Kompas.com: https://health.kompas.com/read/2013/12/12/1207102/sebab.dan.cara.cegah.kontaminasi.makanan

Hardinsyah. (2011). Puasa sambil Detoks, Memurnikan Kembali Body, Mind dan Soul. Jakarta: PT. Gramedia Widiasarana Indonesia.

Heath., Deanne, L., \& Panaretto, S.K. (2005). Original article nutrition status of primary school children in Townsville. J. Rural Health, $13,282-289$

Kementerian Kesehatan RI. (2013). Peraturan Menteri Kesehatan RI No 2 Tahun 2013 Tentang Kejadian Luar Biasa Keracunan Pangan. Jakarta: Kemenkes RI.

Lewis, C. (2002). The "Poison Squad" and The Advent of Food and Drugs Regulation. USA: FDA Consumer Magazine.

Mayasari. D., Mardiroharjo. N., (2012). Pengaruh pemberian boraks peroral sub akut terhadap terjadinya atrofi testis tikus putih jantan (Rattus novergius Strain Wistari). Jurnal Fakultas Kedokteran Universitas Muhammadiyah Malang, 8 (1), 22-27.

Mentri Kesehatan RI. (2012). Peraturan Menteri Kesehatan Republik Indonesia Nomor 033 Tahun 2012 tentang bahan tambahan pangan. Jakarta: KEMENKES RI. 
Nadiya, A. N., \& Asharina, I. (2016). Beberapa mikroba patogenik penyebab foodborne disease dan upaya untuk menurunkan prevalensi foodborne disease Di Indonesia (Mikroba dalam Foodborne Disease dan Pencegahannya). Fermenstation, 1-7.

Nevrianto, R. (1991). Ancaman boraks lewat bakso. Jakarta: PT.Grafiti

Pongsavee, M. 2009. Effect of borax on immune cell proliferation and sister chromatid exchange in human chromosomes. Journal of Occupational Medicine and Toxicology, 4, 1 - 6.

Pratiwi, Y. S. (2018). Mekanisme kerja kulit manggis (Garcinia mangostana L.) dalam mencegah dan menghambat progresivitas kerusakan sel hati akibat penggunaan boraks sebagai zat aditif makanan ([Studi Eksperimental pada Tikus Percobaan (Rattus norvegicus)]). [Thesis Ph.D]. Retrieved from Fakultas Kesehatan Masyarakat, Universitas Airlangga: http://sinta2. ristekdikti.go.id/ affiliations/detail?page=11\&view=ipr\&id=406

Puspadewi, A. (2012). Pemberian Alpha Lipoic Acid (ALA) oral dapat menurunkan kadar malonaldehid (MDA\} darah tikus wistar (Rattus Norvegicus) yang Diinduksi Boraks Secara Oral [ThesisPascasarjana]. Denpasar: Universitas Udayana.

Suadayana, I. T. S, Arania. R, Alfarisi, R,. (2014). Perbedaan pengaruh pemberian boraks terhadap gambaran histopalogi organ ginjal tikus putih jantan (Rattus Norvegicus) galur wistar. Jurnal Ilmu Kedokteran dan Kesehatan, 1 (2), 112-118.

Subiyakto,M. G. (1991). Bakso, boraks dan bleng. Jakarta: PT.Gramedia.

Tatukude, Loho, L., \& Lintong, M.P. (2014). Gambaran histopatologi hati tikus wistar yang diberikan boraks. Jurnal e-Biemedik (eBM), 2 (3), 1-7.

Widelia, P., Farazald, J., \& Narti, M. (2017). Identifikasi Kandungan Boraks Pada Mi Basah Di Pasar Tradisional Kota Bengkulu. Journal of Nursing and Public Health, 58-62.

World Health Organization. (2020). Key fact. Retrieved from World Health Organization: https://www.who.int/en/news-room/factsheets/detail/food-safety

Yusuf, A. R, \& Nisa, K., (2015). Efektifitas buah tomat sebagai penghambat kerusakan hepar akibat boraks. Jurnal Aromed Unila, 2 (3), 284-289.

Zazili., H. (2016). Model Pemberdayaan Konsumen terhadap Ancaman Bahaya Produk Pangan Tercemar Bahan Berbahaya Beracun di Provinsi Lampung. Jurnal Hukum IUS QUIA IUSTUM, 3 (23), 391 - 414 